\title{
Characterisation of construction materials: a chemical comparison of historical mortars
}

\author{
J. R. Ruiz-Checa, V. Cristini, M. O. Valcuende-Payá \\ \& L. Osete-Cortina \\ Universitat Politécnica de Valéncia, Spain
}

\begin{abstract}
This text outlines the results obtained in a case study about construction materials analysis, concerning a set of watchtowers scattered throughout the territory of Cuenca Province, Spain. The complete understanding of these buildings has been possible thanks to different approaches. Territorial analysis, historic study, surveys and construction definition have been the key-factors of architectural research. But a good result could not be possible without a rigorous chemical study. Samples carried out on mortars from different watchtowers have been compared and analyzed. In this frame, a wide range of microanalysis methods has been applied to the samples (i.e. light microscopy, FTIR spectroscopy, scanning electron microscopy-X-ray, X-ray diffraction, granulometric analysis, insoluble residue) with the purpose of confirming the constructive homogeneity and technology of the buildings, as interesting examples of Spanish Christian Reconquest.
\end{abstract}

Keywords: micro and macro mortar characterisation, lime, masonry.

\section{Introduction}

Over the centuries, the typology of the tower has adjusted itself flexibly to the requirements demanded by different functions. Some of these solutions can be summarized mainly as follows: shelter tower, tower-lighthouse, tête-de-pont, toll tower, residential tower, tower tomb, wind tower and barn tower among others (Fig. 1). In the case studied, linked to an inland rural area of Spain, watchtowers are primarily built for the occupation of dispersed rural areas, defined at the time as encastellation [1]. This process is considered as the expansive response of a society that lives a huge demographic and economic vitality in the $11^{\text {th }}$ century [2]. Other authors have further clarified this concept, wedging it as encellulement 
of society [3]. That is to say, a process by which the population is structured around small organized territories, formed city centres, often around a fortification. All this organization facilitates the appropriation of the site by the community. Consequently, the studied towers become a tangible material manifestation of the phenomenon of Repopulation and the Christian Reconquest in Spain $\left(11^{\text {th }}\right)$.

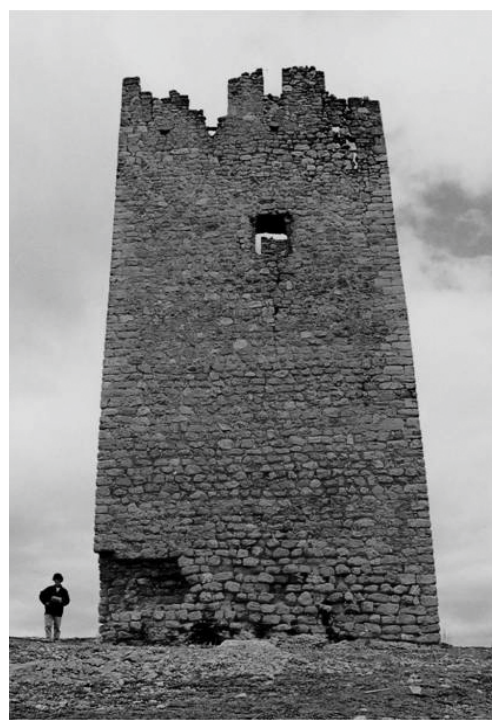

Figure 1: $\quad$ East elevation, tower of Piqueras (case study).
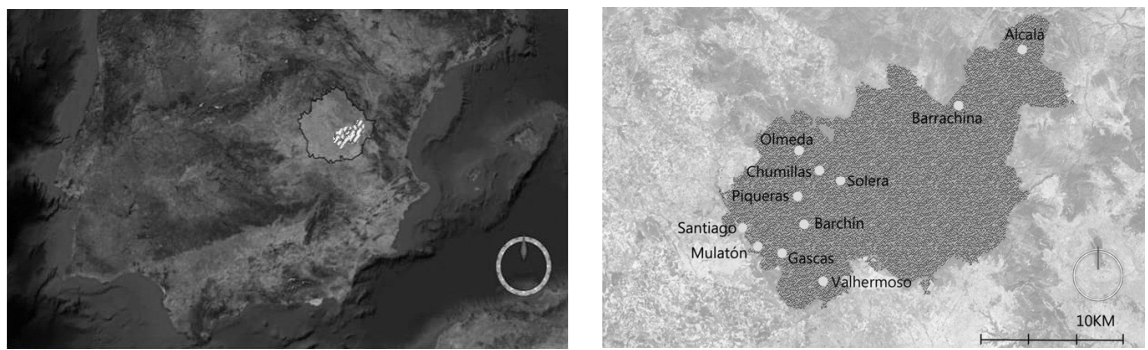

Figure 2: Area of study, Cuenca Province, Spain.

The research focuses on eleven historical buildings, from an introductory regional vision to individual detailed analysis. In particular, the research focuses on the Tower of Piqueras (Piqueras del Castillo), the Tower of Barrachina (Villar del Humo), the Tower of Valhermoso (Valhermoso de la Fuente), the Tower of Solera (Solera de Gabaldón), the Tower of Chumillas (Chumillas), the Tower of Barchín (Barchín del Hoyo), the Tower of Alcalá (Alcalá de la Vega), the Tower of Olmeda (Olmeda del Rey), the Tower of Mulatón (Buenache de 
Alarcón), the Tower of Santiago (Honrubia) and the of Tower Gascas (Gascas) (Fig 2). The foundation of the research is in the tracing of the socio-economic and cultural technique linked to the Medieval Municipal Charters Fuero de Cuenca (1180-1210). Thus the idea is to understand a complex area of study, due to the interlaced influences of the many cultures that habited this area (Iberians, Visigoths, Romans, Muslims or Christians [4].

\section{Methodology}

The research establishes the main features that link the origin of these towers to important references, such as the architecture of repopulation and vernacular architecture, in a defined chronological and geographical setting [5]. To this end, on the one hand an analysis of a wide geographical area (approx. $2740 \mathrm{~km}^{2}$ ) has been carried out, using the DSM system (Digital Soil Mapping) and GIS technology. On the other hand the research has focused on indirect sources (such as cartography or the consultation of historical documents) and on direct sources, such as in situ building surveys. This analysis has generated an exhaustive collection of geographical, territorial, metrical and constructive data (Fig. 3).
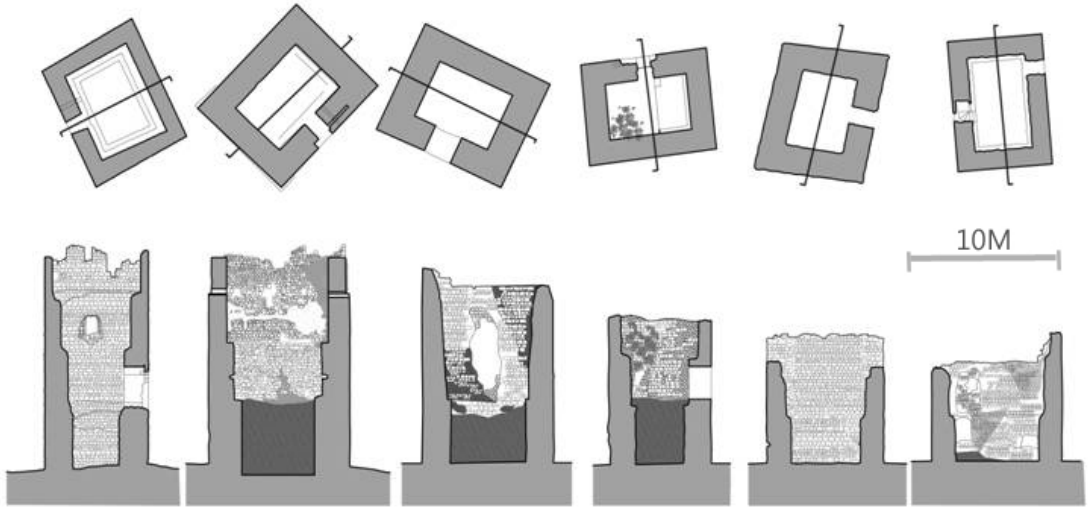

Figure 3: Details of some surveys' results (comparison of layouts and sections).

\subsection{Territorial analysis}

The surface, that the study includes, is an area of approximately $2740 \mathrm{~km}^{2}$. For this reason, due to the huge extension of the analysed territory, some planned and scheduled stages of study were recommended. Definitively this research is opened to different disciplines that allow go deeply into the origin and role played by these towers through the ages.

The study begins with the comprehension of the area where the towers are built with reference to physical, ecological and geological aspects [6].

After this regional vision, the work tries to focus on historical data and sources, to establish the construction age of the towers, their features and their 
relation with other detached buildings of the area (like churches, for examples). The road links are important elements to consider in the anthropological study of the area, because these connections completely cross Cuenca's Province throughout the centuries. The historical paths, bonded with the local cattle raising economy, are fundamental for the complete comprehension of the evolution of the landscape and for the understanding of the presence of the towers. From the first Iberian villages to the ancient Roman's routes net, from Visigoth legacy to Muslim/Christian employment. Always, throughout History, the trades and the woollen activities feed the maintenance of the territory and its roads links [7]. The territory where the towers are located has been so little altered by such external agents like, infrastructures or human changes through the ages (Fig. 4). For this reason the group of towers is an interesting example of defensive typology in the region, showing their resemblance along the topography of the country.

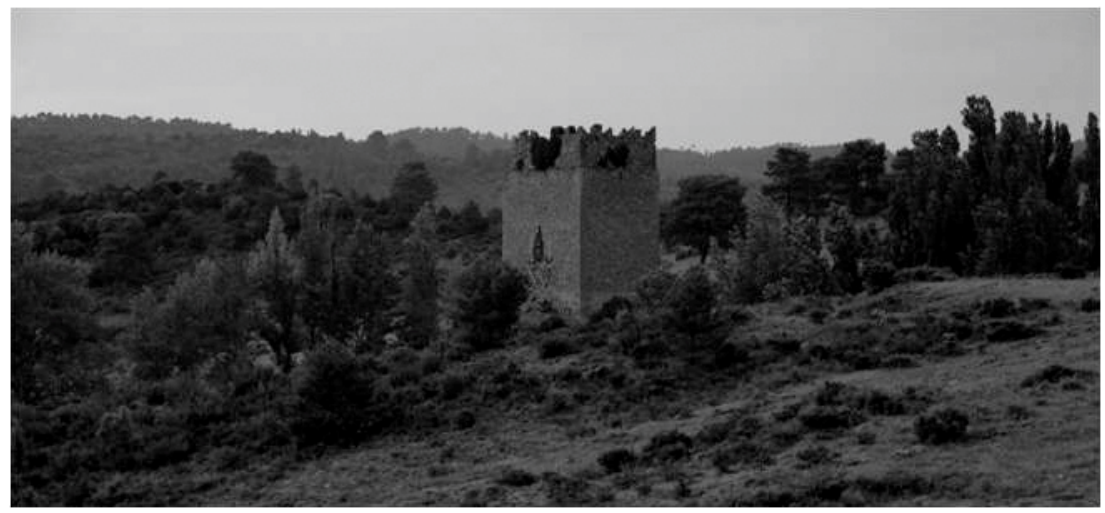

Figure 4: Location and landscape in the Tower of Barrachina.

The analysis has shown that the towers present some objective and repeated features, visible in all the cases of study. For example the location of the watchtowers is on top of reduced rocky platform and their situation is constantly in a narrow valley close to a creek or river. In each case of study the towers are flanked, by routes, ways or paths which are tracing in general with a specific orientation. As a matter of fact, the position of the buildings is related to the cattle raising roads, usually crossing the Peninsula from North to South. The function of these towers, therefore, is deeply related to the control of the routes and passes more than that with an exclusive warlike function [8]. In the analysis of possible visual relations among these buildings, it is verified that the watchtowers are not connected to one another. Visual basins are generated from each tower, thanks to the management of the cartographic information (going on from a two-dimensional vision to a three-dimensional one) and data confirm that the towers are not visually connected [9].

Rather, on the contrary, the visual basins are complementary, covering the surface of every municipal area. This might confirm the watch role of the buildings in the control of the territory, based on visual complementation and 
complete managing of lands. Each visual basin covers a detached area, and this surface is controlled by $40-50$ inhabitants, that play a colonizer role, in a land that has been abandoned for 150 years. These inhabitants, coming from the north regions of the Peninsula, progressively settled in this free territory, in spite of hostile climatic conditions, thanks to special social and legal advantages, in a territorial frame that could be define as a collection of visual basins, as a plot's mosaic.

\subsection{Construction homogeneity}

After the territorial outlining of these watchtowers, it's also interesting to underline a second level of analysis, bonded with geometrical and dimensional aspects. In spite of their level of conservation, all the towers present a squared layout $(8 \times 10 \mathrm{~m})$ featured inside by three levels of access. A huge wall section that gradually is reduced towards the top of the buildings, characterized the constructions (from $0.45 \mathrm{~m}$ to $2 \mathrm{~m}$ ). The main entrance of the watchtowers is $5 \mathrm{~m}$ high (it's still visible in Alcalà de la Vega, Barrachina, Piqueras del Castillo, Solera, Valhermoso and Chumillas examples). This vain is not due to special orientation criteria, better it's a connection that answers to local elements, like rivers, paths or water sources. The original opening-closing door system is still present in some towers examples; these cases presents holes for timber trunks quite visible in the jambs, frequently covered by a raw vault, $1.5 \mathrm{~m}$ broad [10].

Thanks to the survey's results a constructive module is discovered, as guideline for watchtowers building sites. A measure system, based on $0.835 \mathrm{~m}$ module (vara castellana) is visible in the constructive strategy. And this is the same measure used in cities like Burgos, Guadalajara, Cuenca (south) for detached examples of Romanesque architecture. This constructive module, originally born in North areas of the Peninsula, is a proof of repopulation footprint and its social and cultural legacy in southern areas [11].

A first attempt of masonries' classification, which follows this module criteria and possible variations through the centuries, has been recently summarized by the authors. One detached result, in this frame, is underlined by a type of masonry, identified in the area of study, as in watchtowers walls as in medieval religious buildings (made by squared, well coursed shaped-middle size stone bonding). It's a frequent technique visible in Romanesque architecture, in regions previously under the control of Roman Empire [12] and it's based on a double-wythe wall filled with rubble and mortar. Also some others parts of these watchtowers structures, like stone corners, inner sections of the walls or stone arches reflect this feature.

\subsection{Raw materials chemical study}

To make possible the complete understanding of this set of watchtowers, another important study has been done by the authors. Raw material definition is a way to understand, justify and underline the construction reasons and criteria of these watchtowers, during the Spanish Reconquest. For one hand it's important to consider that stones are collected by local builders, thanks to narrow raw material (the walls are randomly mixed up with limestone, sandstone or 
conglomerates according to main geological facies). For the other, it's interesting to notice that some detached aspects can be discovered in mortars featuring, thanks to chemical analytical studies, as following explained. With the aim of obtaining information about all these samples, light microscopy, FTIR spectroscopy, scanning electron microscopy-X-ray microanalysis, X-ray diffraction and grain-size analysis have been carried out. Samples analysis (as macroscopic as microscopic scale) has been carried out with the purpose to check and compare different types of mortars, as principal raw material employed in the towers, both with stones. Different relations have been established, starting from visual analysis and progressively getting to grain-size analysis. Finally, thanks to this approach, a collection of raw material data has been defined, as following explained.

\section{Experimental data}

Sampling was carried out on mortars from different watchtowers studied, from both the interior and the exterior of the masonry reports the samples, their reference, location and historical period of construction. Specifically Barrachina tower (BARR), Chumilla tower (CHU), Alcalà tower (ALC), Piqueras tower (PIQ), Solera tower (SOL) and finally Valhermoso tower (VAL) have been analyzed, thanks to their good level of preservation. Inner mortars (Int) and finishing mortars (Ext) of the double-wythe wall filled with rubbles and mortar have been object of study.

\subsection{Light microscopy and FTIR spectroscopy}

Representative fragments of the samples studied were embedded in polyester resin (Ferpol 1973, Ferocast, Comercial Feroca, S.A., Madrid) and then mechanically polished with abrasive papers to a 4000 silicon carbide grit finish in a polishing machine (Knuth-rotor 2, Struers, Erkrath, Germany) for their morphological examination under a stereoscopic light microscope Leica S8AP0 (Leica Microsystems, Heidelberg, Germany) equipped with a Leica Digital FireWire Camera (DFC) (Fig. 5).
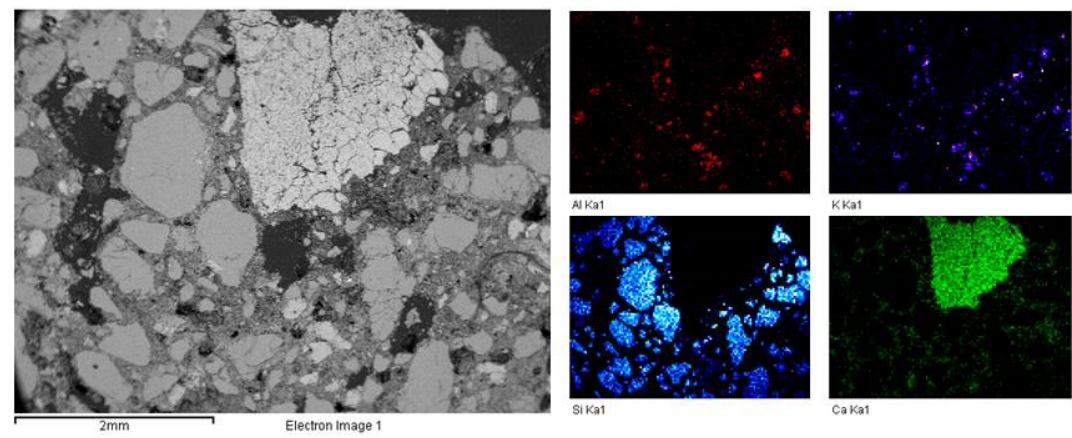

Figure 5: Elemental distribution of sample BARR EXT. 
The IR spectra in the ATR mode of the powdered samples were obtained using a Vertex 70 Fourier-transform infrared spectrometer with an FR-DTGS (fast recovery deuterated triglycine sulphate) temperature-stabilised coated detector and a MKII Golden Gate Attenuated Total Reflectance (ATR) accessory. A total of 32 scans were collected at a resolution of $4 \mathrm{~cm}^{-1}$ and the spectra were processed using the OPUS/IR software.

\subsection{Scanning electron microscopy-X-ray microanalysis}

Chemical composition of the samples prepared as cross-sections was obtained using a Jeol JSM 6300 scanning electron microscope operating with a LinkOxford-Isis X-ray microanalysis system. The analytical conditions were: $20 \mathrm{kV}$ accelerating voltage, $2 \times 10^{-9} \mathrm{~A}$ beam current and $15 \mathrm{~mm}$ as working distance. Samples prepared in polished cross-sections were carbon coated to eliminate charging effects. Quantitative microanalysis was carried out using the ZAF method for correcting interelemental effects. The counting time was $100 \mathrm{~s}$ for major and minor elements. The standards used were the following minerals: Albite (Na), $\mathrm{MgO}(\mathrm{Mg}), \mathrm{Al}_{2} \mathrm{O}_{3}$ (Al), Quartz (Si), GaP (P), FeS 2 (S), MAD-10 feldspar (K), Fe (Fe), Mn (Mn), wollastonite (Ca), Ti (Ti), $\mathrm{PbF}_{2}(\mathrm{~Pb}), \mathrm{Cr}(\mathrm{Cr})$, $\mathrm{Hg}(\mathrm{HgTe}), \mathrm{Ba}\left(\mathrm{BaF}_{2}\right), \mathrm{As}(\mathrm{InAs}), \mathrm{Cl}(\mathrm{KCl})$. Element percentages were generated by ZAF software on the Oxford-Link-Isis EDX.

\subsection{X-ray diffraction, granulometric analysis and insoluble residue}

XRD diffractograms were acquired by using a Bruker D8 Advanced A25 diffractometer equipped with a Lynxeye fast detector. XRD patterns were collected covering 5-80 $2 \theta$ with an exposition time of $0.8 \mathrm{~s} . \mathrm{Cu} \mathrm{K}_{\alpha}$ radiation was used (40 kV and $40 \mathrm{~mA})$. With the aim of obtaining information on the granulometric distribution of the mortars (grain size distribution and aggregate: binder proportion), the mortar samples were carefully disaggregated and sieved through international test sieve series (ISO 3310:2000, meshes of 8, 4, 2.5, 1, $0.800,0.250,0.125,0.100,0.080,0.063 \mathrm{~mm})$.

For the determination of the insoluble residues a small representative portion of the aggregate and binder fractions were digested in dilute hydrochloric acid (1:3 volume ratio). The insoluble residue, corresponding to the siliceous materials present in the mortars, was then filtered and weighted to obtain the weight percentage of the siliceous fraction.

\section{Results and discussion}

\subsection{Macroscopic analysis/granulometric study}

Observation of the samples evidenced their heterogeneity, as corresponds to filling mortars, integrated with large-size gravel, and pointed out different degrees of cohesion, depending on the state of conservation of each mortar. In this sense, samples CHU INT, BARR EXT, BARR INT, SOL EXT and, especially SOL INT, showed lesser degree of consistency in comparison with the 
rest of the mortars, and tended to suffer important losses of matter with their handling. For the characterisation of the samples from a granulometric point of view, grain size distributions of the mortars were obtained after disaggregation and sieving. In almost all the samples, the predominant fractions were retained in the meshes of 1 and $0.250 \mathrm{~mm}$ and turn to be about $50 \%$ of the sieved material, and the average proportion of binding material $<0.063 \mathrm{~mm}$ ranges between 1 and $5 \%$. The granulometric distribution indicates a significant content of grains with size larger than $2.5 \mathrm{~mm}$ (gravel-size aggregate). On the other hand, the granulometric fraction $>8 \mathrm{~mm}$ presents a wider range of weight percentage that varies, depending on the sample, between 5 and $34 \%$, which is in concordance with the type of materials studied.
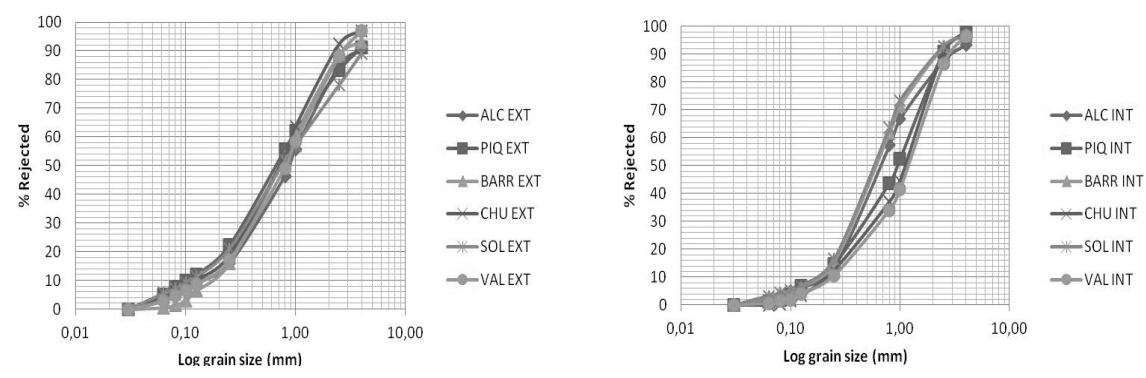

Figure 6: Granulometric curves for the samples from the exterior and interior of the masonries without considering the fraction of $8 \mathrm{~mm}$.

The corresponding cumulative granulometric distributions obtained for the samples analyzed present a good fit between them. Only samples ALC EXT and SOL EXT differ from the others. As for the mortars from the interior masonries, ALC INT and SOL INT showed the highest deviations, too. Taking into account that the most significant differences between the set of samples studied correspond to the biggest granulometric fraction $(>8 \mathrm{~mm})$, grain size distributions were represented again without considering the material with this size. In this case, all the granulometric curves for the finishing mortars fit perfectly, which could be related to the use of sand of the same provenance, whereas for the inner mortars, samples ALC INT, BARR INT, and SOL INT exhibited a slightly different granulometric profile (for the medium-size grains) from the rest of samples. The differences observed for the mortar SOL INT could be associated to losses of material of medium-fine grain size, due to its higher degree of alteration, whereas for samples ALC and BARR, form the towers located in the North of the region, the deviations observed could be related to small variations in the elaboration technique. The results of the granulometric distributions allow the estimation of an aggregate: binder ratio (A/B) between 5 and 6:1 for the finishing mortars and an average of 8:1 for most of the samples from the interior of the masonries (Fig. 6). 


\subsection{Light microscopy and infrared spectroscopy (FTIR)}

Examination of the corresponding polished cross-sections by light microscopy evidenced similar textural features between them. All of them exhibit a very heterometric distribution of aggregate grains with a sub-angulous and subrounded morphology and with different color (brown, translucent, white and beige), and an ochre binder. The occurrence of very large whitish aggregates (with a maximum diameter up to $1.7 \mathrm{~cm}$ ) with a porous texture associated to lime nodules, and charcoal fragments with a wide size range (from few $\mathrm{mm}$ to $2.2 \mathrm{~cm}$ ), was observed in the samples, and only in ALC INT mortar, fossils were identified. These morphological features are in concordance with the kind of samples studied: highly heterogeneous and elaborated employing traditional techniques without an exhaustive selection of the raw materials, a lack of homogeneity in the mix, and confirm the extensive transport undergone by the materials used as aggregate form the source area. Mineralogical characterisation by means of FTIR Spectroscopy confirmed that all samples are lime mortars, according to the occurrence of bands of calcite $\left(\mathrm{CaCO}_{3}\right)$, as main mineralogical phase identified in the infrared spectra obtained for the granulometric fraction of the binders (particle size $<0.063 \mathrm{~mm}$ ).

Both interior and exterior masonry mortars are characterize by a similar mineralogical composition, based on the presence of calcite $(2520,1795,1392$, 871,850 and $\left.711 \mathrm{~cm}^{-1}\right)$, quartz $\left(1162,1086,1003,800,774 \mathrm{~cm}^{-1}\right)$ and phyllosilicate minerals $\left(3691,3622,1638, \mathrm{~cm}^{-1}\right)$ [13]. Absortion bands of quartz are related to fine grains of aggregate passed through a 0,063 mm-size sieve [14].

\subsection{X-ray diffraction (XRD) and (SEM/EDX)}

The mineralogical composition of the binder of the mortars obtained by X-ray diffraction is in agreement with the results obtained by Infrared Spectroscopy previously reported. Calcite is the main crystalline phase, and in a minor proportion, quartz, feldspars, dolomite and phyllo-silicate minerals (kaolinitetype) are identified, and only in sample PIQ INT halite was detected. Taking into account that the monument is located far from the sea, thus the environment surrounding the tower presents a low salinity. The occurrence of halite in this sample could be due to an intentional addition to the mortar with the aim of accelerating the carbonation process [15]. Infrared Spectroscopy analysis of the aggregate fraction revealed their mixed nature, due to the identification of bands characteristic of calcite and siliceous minerals. For most of the samples, quartz and feldspars $\left(1162,1073,795,777,693 \mathrm{~cm}^{-1}\right)$ and phyllo-silicate minerals $\left(3691,3622,1638, \mathrm{~cm}^{-1}\right)$ are the most abundant siliceous compounds in the aggregate.

Infrared spectra for the aggregates of samples ALC EXT y CHU INT are depicted. Spot scannings made by SEM/EDX in the aggregate grains of the mortars confirmed their mixed nature.

In samples BARR, CHU, PIQ, SOL and VAL, the siliceous content is predominant, mainly for the sand-size grains, as was observed in the spot distributions of elements acquired, whereas for sample ALC, the analysis 
revealed that the carbonatic fraction is more abundant, in concordance with the results obtained by FTIR spectroscopy (Table 1). With the aim of completing the results from the mineralogical analysis, insoluble residue of the aggregate fraction was obtained. For most of the samples studied, insoluble residue ranges between 60 and $86 \%$ weight, indicating their predominant siliceous nature, except for the samples ALC EXT and ALC INT, with a carbonatic aggregate, according to the insoluble residue obtained (20-30\% weight).

Table 1: Quantitative analysis of binders by SEM/EDX.

\begin{tabular}{|c|c|c|c|c|c|c|c|c|c|}
\hline Sample & $\begin{array}{l}\mathrm{Na}_{2} \mathrm{O} \\
(\mathrm{w} \%)\end{array}$ & $\begin{array}{l}\text { MgO } \\
(\mathrm{w} \%)\end{array}$ & $\begin{array}{l}\mathrm{Al}_{2} \mathrm{O}_{3} \\
(\mathrm{w} \%)\end{array}$ & $\begin{array}{l}\mathrm{SiO}_{2} \\
(\mathrm{w} \%)\end{array}$ & $\begin{array}{c}\mathrm{SO}_{3} \\
\left(\mathrm{w}^{0} 0\right)\end{array}$ & $\begin{array}{l}\mathrm{K}_{2} \mathrm{O} \\
(\mathbf{w} \%)\end{array}$ & $\begin{array}{c}\mathrm{CaO} \\
(\mathrm{w} \%)\end{array}$ & $\begin{array}{l}\mathrm{TiO}_{2} \\
(\mathrm{w} \%)\end{array}$ & $\begin{array}{c}\text { FeO } \\
(w \%)\end{array}$ \\
\hline $\begin{array}{l}\text { ALC } \\
\text { EXT }\end{array}$ & - & 1.24 & 1.60 & 4.38 & 1.32 & 0.41 & 90.34 & - & 0.71 \\
\hline ALCINT & - & 2.79 & 2.59 & 11.39 & 0.80 & 0.61 & 80.32 & - & 1.49 \\
\hline $\begin{array}{l}\text { BARR } \\
\text { EXT }\end{array}$ & 0.91 & 12.60 & 2.15 & 16.26 & 1.02 & 3.19 & 61.28 & $\cdot$ & 0.52 \\
\hline $\begin{array}{l}\text { BARR } \\
\text { INT }\end{array}$ & 0.57 & 12.04 & 4.42 & 18.08 & 0.89 & 1.35 & 61.25 & - & 1.04 \\
\hline $\begin{array}{l}\text { CHU } \\
\text { EXT }\end{array}$ & - & 1.13 & 3.77 & 8.35 & 0.54 & - & 85.51 & - & 0.70 \\
\hline CHUINT & 3.32 & 1.50 & 1.42 & 11.88 & - & 1.41 & 75.72 & - & 0.70 \\
\hline PIQ EXT & 0.55 & 10.65 & 5.49 & 17.59 & 0.96 & 2.19 & 60.44 & 0.37 & 1.40 \\
\hline PIQ INT & 5.14 & 1.79 & 2.32 & 13.81 & - & 1.58 & 71.02 & - & 0.47 \\
\hline SOLEXT & 1.00 & 9.76 & 4.68 & 13.91 & 3.78 & 5.60 & 58.21 & - & 1.33 \\
\hline SOLINT & - & 7.29 & 1.32 & 6.70 & 1.41 & 0.53 & 82.75 & - & - \\
\hline $\begin{array}{l}\text { VAL } \\
\text { EXT }\end{array}$ & 0.73 & 0.69 & 0.72 & 7.94 & 0.80 & 3.82 & 82.78 & - & 1.16 \\
\hline VALINT & 0.72 & 1.73 & 0.47 & 4.86 & 1.79 & 0.41 & 89.01 & - & 0.37 \\
\hline
\end{tabular}

\subsection{Principal component analysis (PCA)}

Finally, a chemometric study based on principal component analysis (PCA) was carried out on the results obtained from the analyses described above in order to compare the chemical and granulometric features of the samples. Taking into account the heterogeneity of the samples studied, the results of the PCA suggest differences between the samples depending on geology (Fig. 7).

\section{Conclusions}

The research has established that these buildings are not isolated elements, but are a group of monuments, deeply related and rooted to the landscape and the territory. So, in this framework, the constructive system of the towers, the way of their implantation in the landscape, their dating, their relation with road links are fundamental keys for their study, as part of the Reconquest Architecture.

Certainly these watchtowers answer to a constructive basic system, which is closer to the beginning of a Romanesque architecture of Repopulation. The new settlers of the Reconquest, devoted themselves to execute their works with a 


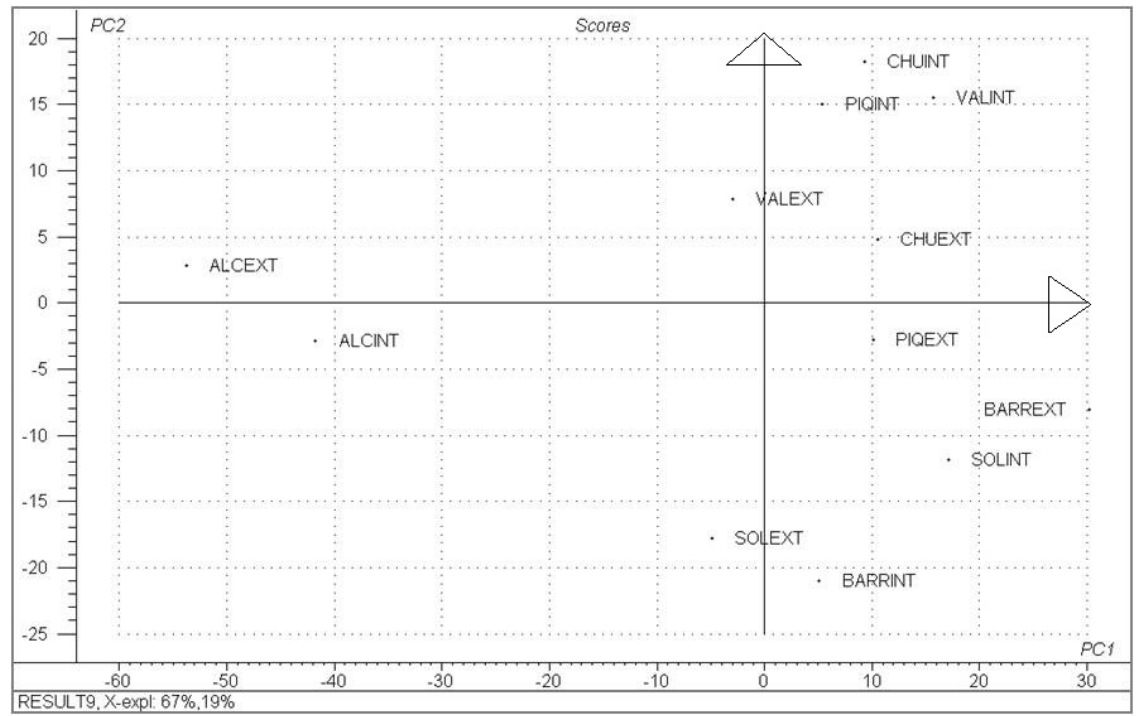

Figure 7: PCA on samples considering as variables for the study the weight percentages of the most representative granulometric fractions $(2.5 \mathrm{~mm}, 1 \mathrm{~mm}, 0.25 \mathrm{~mm}$ and $<0.063 \mathrm{~mm})$ the aggregate/binder ratios, the weight percentage of the insoluble residue after the acid attack for the aggregate (\% IRa) and binder fractions ( $\%$ IRb), and the weight percentage of $\mathrm{MgO}(\% \mathrm{Mg})$ and $\mathrm{FeO}(\% \mathrm{Fe})$ obtained by $\mathrm{SEM} / \mathrm{EDX}$.

standardized constructive technique, based on solid and austere constructions with double-wythe wall filled with rubbles and lime mortar. Thanks to the results of the territorial study, the collation of constructive features and the analysis of stone and mortar samples it has been possible to extract information reflecting both semantic-symbolic and material-technical aspects. At the same time, it has been possible to understand the historical context and the reasons behind the building of the iconic constructions of the region. Definitively the towers present a detached uniformity, above all in terms of territorial planning, squared layout, levels, accesses, and also measure system. Based on $0.835 \mathrm{~m}$, a Spanish traditional measurement system named vara castellana. Concerning the mortars study it's interesting to underline some conclusions too. Above all, the results of the granulometric distributions allow the estimation of an aggregate/binder ratio between 5 and 6:1 for the mortars (from the exterior walls) and an average of $8: 1$ for most of the samples (from the interior of the masonries). It's also interesting to underline that the mineralogical composition of the binder of the mortars obtained by X-ray diffraction is in agreement with the results obtained by Infrared Spectroscopy: all the samples are lime mortars and in a minor proportion, quartz, feldspars, dolomite and phyllo-silicate minerals (kaolinite-type). At the same time aggregates are quite heterogeneous 
(above all granulometric fraction $>8 \mathrm{~mm}$ ) as an answer to local resources, geological facies and approximate and quickly selection and preparation of raw materials (also charcoal fragments and lime nodules have been found).

\section{References}

[1] P. Toubert, M.A. Galmarini, R. Pastor de Togneri, R., Castillos, señores y campesinos en la Italia medieval. Crítica Ed., Barcelona, 1990.

[2] F.J. Faci Lacasta, Algunas observaciones sobre la obra de Pierre Toubert in Incastellamento: actas de las Reuniones de Girona y de Roma, CSIC Ed., Madrid, 1998.

[3] R. Fossier, Enfance de l'Europe Xe-XIIe siecle: aspects économiques et Sociaux, Presses Universitaires de France Ed., Paris, 1989.

[4] J. González, Repoblación de Castilla la Nueva. UCM Ed, Madrid, 1975.

[5] M.A. Monedero Bermejo, La arquitectura de la repoblación en la provincia de Cuenca, Excma. Dip. Prov. Cuenca Ed., Cuenca, 1982.

[6] L. García de Pedraza, A. Reija Garrido, Tiempo y clima en España: Meteorología de las autonomías, Dossat Ed., Madrid, 1994.

[7] J. Klein, La Mesta: estudio de la historia económica española. Alianza, Madrid, 1990.

[8] J.R. Ruiz Checa, V. Cristini, Mapping of mortars and ashlars in watchtowers of Reconquest Ages in Cuenca District, Spain in 2nd Historic Mortars Conference Repair for Historic Masonry, Institute of Theoretical and Applied Mechanics, Prague, 2010.

[9] J.R. Ruiz Checa (Et Al.) Empleo de modelos tridimensionales aplicados al estudio histórico arquitectónico del territorio in Virtual Archaeology Review. UCLM Ed., 2011.

[10] J.R. Ruiz Checa, V. Cristini, Caracterización constructiva de las fábricas medievales en el ámbito del Fuero de Cuenca (s. XII) in Arché. Revista del Instituto de Restauración del Patrimonio de la UPV, UPV Ed., Valencia, 2012, pp. 320-330.

[11] J.M. Merino de Cáceres, Planimetría y metrología en las catedrales Españolas in Metodología de la restauración y de la rehabilitación. Ed. Munilla Lería, Madrid, 1999.

[12] J. Adam, La construcción romana: materiales y técnicas, Los Oficios, León, 1996.

[13] H.W. Van der Marel, H. Beutelspacher, Atlas of Infrared Spectroscopy of Clay Minerals and their admixtures, Elsevier Scientific Publishing Company, New York, 1976.

[14] G. Biscontin, M. Pellizon, E. Zendri, Journal of Cultural Heritage 3 (2002) 31-37.

[15] P. Adriano, A. Santos Silva, R. Veiga, J. Mirão, A.E. Candeias, Materials Characterisation 60 (2009) 610-620. 